\title{
Characteristics of natural biopolymers and their derivative as sorbents for chromium adsorption: a review
}

\author{
Ruoshi Zhang ${ }^{1,2}$ and Yongqiang Tian ${ }^{1,2^{*}}$
}

\begin{abstract}
Chromium is widely used in industry, and improper disposal of wastewater and industrial residues containing excessive chromium can contaminate water and soil, endangering both environmental and human health. Natural biopolymers and their derivatives have been investigated for removal of chromium (Cr) from wastewater. Cellulose, lignin, tannin, chitin, chitosan, and polypeptides are abundant in nature, and have high potential as adsorbents due to their easy access, low cost, and the recyclability of the captured heavy metals. In order to improve their mechanical strength, recyclability, specific surface area, binding site number, and adsorption rate as adsorbents, native materials have also been modified. This review discusses the source of chromium contamination and the main species of interest, as well as their toxicity. The structures of the aforementioned biopolymers were analyzed, and the adsorption mechanism of chromium and the main influencing factors on this process are discussed. The modification methods of various adsorbents and their adsorption effects on chromium are also detailed, and the developmental direction of research on the use of biopolymer adsorption remediation to control chromium contamination is discussed.
\end{abstract}

Keywords: Biopolymer, Adsorbent, Adsorption, Chromium

\section{Introduction}

Chromium-containing chemicals are wildly used in many industries such as leather tanning, the mining of chrome ore, metal finishing, pigment manufacturing, and wood preservation [1]. Over the past few decades industrialization has accelerated, and the amount of chromium in aquatic and terrestrial ecosystems has increased [2]. There are relevant regulations on the threshold of chromium content in water and soil. Many countries have established $50 \mu \mathrm{g} / \mathrm{L}$ as the maximum permissible limit of total chromium in drinking water [3]. In China, the risk control values of chromium pollution in agricultural soil are $800 \mathrm{mg} / \mathrm{kg}(\mathrm{pH} \leq 5.5), 850 \mathrm{mg} / \mathrm{kg}$

\footnotetext{
* Correspondence: yqtian@scu.edu.cn

'College of Biomass Science and Engineering, Sichuan University, No.24

South Section, 1st Ring Road, Chengdu 610065, PR China

${ }^{2}$ Key Laboratory of Leather Chemistry and Engineering (Sichuan University), Ministry of Education, No.24 South Section, 1st Ring Road, Chengdu 610065, PR China
}

$(5.5<\mathrm{pH} \leq 6.5), 1000 \mathrm{mg} / \mathrm{kg}(6.5<\mathrm{pH} \leq 7.5)$, or $1300 \mathrm{mg} /$ lways been a focus of heavy metal pollution treatment. The traditional methods for treating heavy metal contamination include chemical precipitation, ion exchange, membrane separation, reverse osmosis, evaporation, electrochemical treatment, and adsorption [5-7]. mongst these, the adsorption method has become the wastewater with low concentrations of heavy metals $(<$ fived into synthetic polymers, hybrid polymers, natura polymers, and modified natural polymers. Sophisticated synthetic polymers, polymerized by free radicals, gamma 
radiation, graft, oxidation, or dispersion/suspension, as well as simple synthetic polymers like polyvinylpyridine, polypyrrole, and polyaniline have been used for adsorption of chromium [8]. Natural polymers are also attracting attention due to their low cost and availability. In particular, modified natural polymers combine the advantages of both synthetic and natural polymers, and have been demonstrated to provide improved adsorption capacity. All content discussed further in this review will emphasize natural polymers and modified natural polymers.

Cellulose, lignin, tannin, chitin, chitosan, and polypeptide are all inexpensive and abundant natural polymers, which are renewable, biodegradable, and non-toxic. The large number of hydroxyl groups present on cellulose means that it has a limited ability to bind to metal itself, but these same hydroxyl groups are beneficial to graft functional groups or molecules onto the cellulose structure, thereby improving adsorption capacity [9]. The metal binding capacity of lignin is attributed to functional groups such as phenolic hydroxyl, methoxy, and carbonyl, which can form complexes with metal ions in solution through oxygen-donating electron pairs [10]. The phenolic groups on tannin are easy to deprotonate and form resonance-stablilized phenoxide ions, which gives tannin its anionic nature, while the amino groups on the chitosan can be protonated under acidic conditions, giving chitosan its cationic nature. This polarized nature is critical to the affinity of these compounds towards metal ions [11-13]. The carboxyl, amino, and unique functional groups on the side chains of the various amino acids that make up the polypeptide allow it to bind metals. Numerous functional groups endow these biopolymers with the ability to adsorb metals, but there are significant differences in their adsorption selectivity for Cr. Compared with native cellulose, chitin, polypeptides, chitosan, tannin, and lignin show significant adsorption selectivity for $\mathrm{Cr}$ (VI) in comparison to other metals.

In this paper, chromium species and their toxicity are first discussed, followed by the adsorption mechanism of chromium. The chemical structures and properties of cellulose, lignin, tannin, chitin, chitosan, and polypeptides are outlined, and the functional groups related to adsorption of chromium in various adsorbents and the influencing factors are discussed. Lastly, the adsorption of chromium by the derivatives of the above adsorbents is discussed in detail.

\section{Chromium species and their toxicity}

Chromium exists in several valence states, ranging from zero to hexavalent. Cr (III) and Cr (VI) are the most important and stable valence states found in the environment [14]. Cr (VI) dominates under oxidative conditions, while $\mathrm{Cr}$ (III) dominates under reducing conditions. As is shown in Fig. 1 [15], Cr (VI) in aqueous solution mainly exists in the forms of $\mathrm{Cr}_{2} \mathrm{O}_{7}{ }^{2-}, \mathrm{CrO}_{4}{ }^{2-}$, $\mathrm{H}_{2} \mathrm{CrO}_{4}$, and $\mathrm{HCrO}_{4}{ }^{-}$. This distribution depends on the $\mathrm{pH}$ of the solution, the total $\mathrm{Cr}$ concentration, the existence of oxidizing and reducing agents, the redox potential, and the kinetics of redox reactions. If the $\mathrm{pH}$ of the solution is higher than $7, \mathrm{CrO}_{4}{ }^{2-}$ is the only ion present, but in the $\mathrm{pH}$ range of one to $\mathrm{six}, \mathrm{HCrO}_{4}^{-}$is the dominant substance. $\mathrm{Cr}$ (III) exists as water-soluble $\mathrm{Cr}^{3+}$ cations when the $\mathrm{pH}<3.9$, and the amount of $\mathrm{Cr}^{3+}$ gradually decreases as $\mathrm{pH}$ increases to 5 . When $\mathrm{pH}>5$, $\mathrm{Cr}(\mathrm{OH})^{2+}$ is formed by hydrolysis. While $\mathrm{pH}>6$, water insoluble $\mathrm{Cr}(\mathrm{OH})_{3}$ precipitate is formed. Cr (III) compounds are readily absorbed by soil colloids, forming extremely low solubility deposits that prevent them from seeping into groundwater or being absorbed by plants. In contrast, $\mathrm{Cr}(\mathrm{VI})$ in the form of chromate and dichromate $\left(\mathrm{CrO}_{4}{ }^{2-}, \mathrm{HCrO}_{4}{ }^{-}\right.$and $\left.\mathrm{Cr}_{2} \mathrm{O}_{7}{ }^{2-}\right)$ exhibits strong oxidative and high solubility.

$\mathrm{Cr}$ (VI) is considered highly toxic. High exposure to $\mathrm{Cr}$ (VI) causes cancer in the digestive tract and lungs and may cause epigastric pain, nausea, vomiting, severe diarrhoea, and hemorrhage $[16,17]$. The main toxicity mechanism of $\mathrm{Cr}$ (VI) in prokaryotes and eukaryotes is related to its easy diffusion through the cell membrane. Meanwhile, the reduction of $\mathrm{Cr}(\mathrm{VI})$ in cells leads to the generation of free radicals, which may directly cause DNA changes and other toxic effects [18-20]. Cr (III) is necessary for the normal metabolism of sugars, lipids,

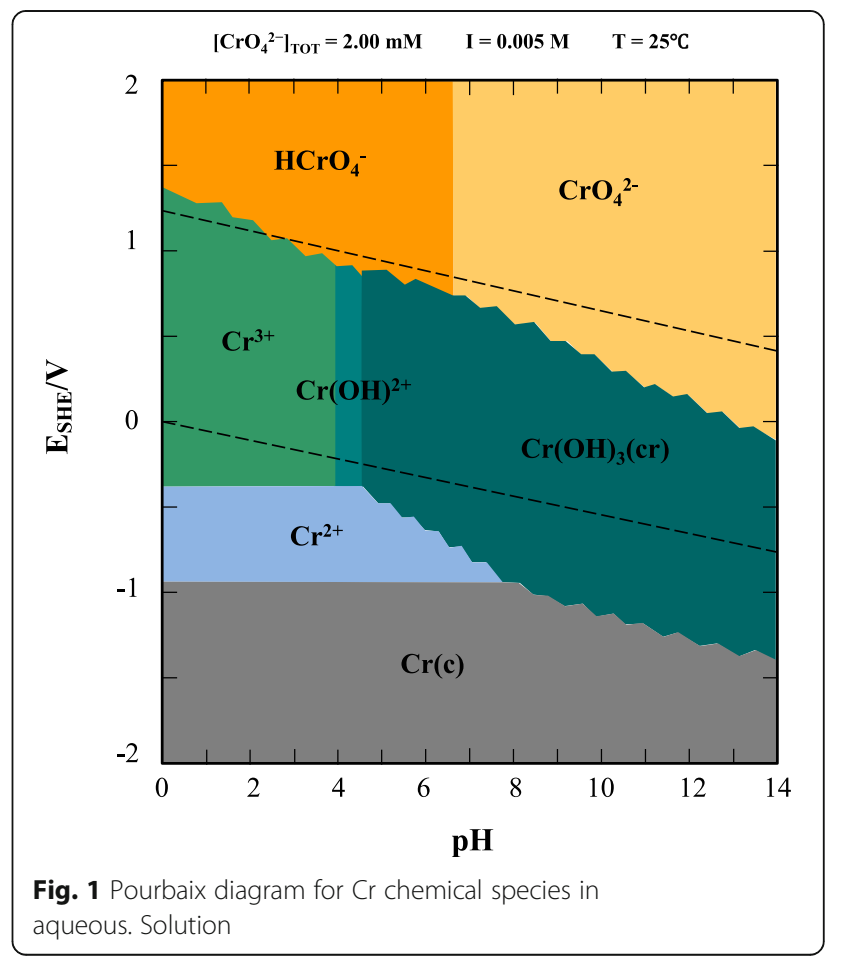


and proteins in mammals, and it is an essential trace element in the diet of animals and humans. Cr (III) potentiates the effect of insulin by facilitating insulin binding to receptors at the cell surface to maintain blood glucose levels [21]. In addition, $\mathrm{Cr}$ (III) has a positive effect on reducing body fat, cholesterol, and triglycerides as well as in increasing muscle mass. Due to the impermeability of the cell membrane to the Cr (III) complex, its toxicity is lower than that of $\mathrm{Cr}$ (VI). However, longterm exposure to $\mathrm{Cr}$ (III) is known to cause allergic skin reactions and cancer.

\section{Adsorption mechanisms}

Generally, metal adsorption can involve many processes, such as electrostatic attraction, ion exchange, chelation of metals with various functional groups, and physical adsorption [22-24]. In addition, the $\mathrm{pH}$ and solution composition will affect the protonation of the adsorbent and the speciation of metal ions, thus having an impact on the mechanism of metal adsorption [25].

\section{1 lonic adsorption mechanism}

Many relevant reports point out that $\mathrm{Cr}$ (VI) adsorption increases at low $\mathrm{pH}$ values and decreases at high $\mathrm{pH}$ values. At low $\mathrm{pH}$ values, the functional groups of biological adsorbents protonate and tend to attract negatively charged $\mathrm{Cr}$ (VI), but at high $\mathrm{pH}$ values, the functional groups become negatively charged and repel negatively charged $\mathrm{Cr}$ (VI). Therefore, for $\mathrm{Cr}$ (VI), the combination of electrostatically charged functional groups on the surface of the biosorbent by electrostatic attraction is one of the main adsorption mechanisms. $\mathrm{Cr}$ (III) ions, on the other hand, are cations and bind to negatively charged adsorbent functional groups at high $\mathrm{pH}$.

\subsection{Adsorption-coupled reduction mechanism}

Park et al. [26] proposed that it was likely possible that the mechanism of $\mathrm{Cr}(\mathrm{VI})$ removal by biomaterials or biomaterial-based activated carbons was not "anionic adsorption", but instead "adsorption-coupled reduction". Experiments were subsequently designed to provide data to support this theory [27]. Specifically, as is shown in Fig. 2 [28], the proposed mechanism includes three steps. Firstly, the $\mathrm{Cr}$ (VI) oxoanion was adsorbed on the positively charged groups of the biosorbents. Following this, the reduction of $\mathrm{Cr}$ (VI) to $\mathrm{Cr}$ (III) was caused by the adjacent electron-donor groups of the biosorbents. Finally, the positively charged Cr (III) was released into the solution due to repulsion with the positively charged functional groups of the biosorbents [29].

Other researchers have found that when chromium was adsorbed, only part of $\mathrm{Cr}$ (VI) was reduced to $\mathrm{Cr}$ (III) before the Cr (VI) anion and Cr (III) cation were simultaneously adsorbed to the biomass. Hasan et al. [30] observed that the color of the surface of the biosorbent turned greenish during sorption. They explained that this was certainly due to the sorption of the reduced form of chromium, Cr (III) (which is greenish in color), on the surface of the adsorbent. Moreover, after

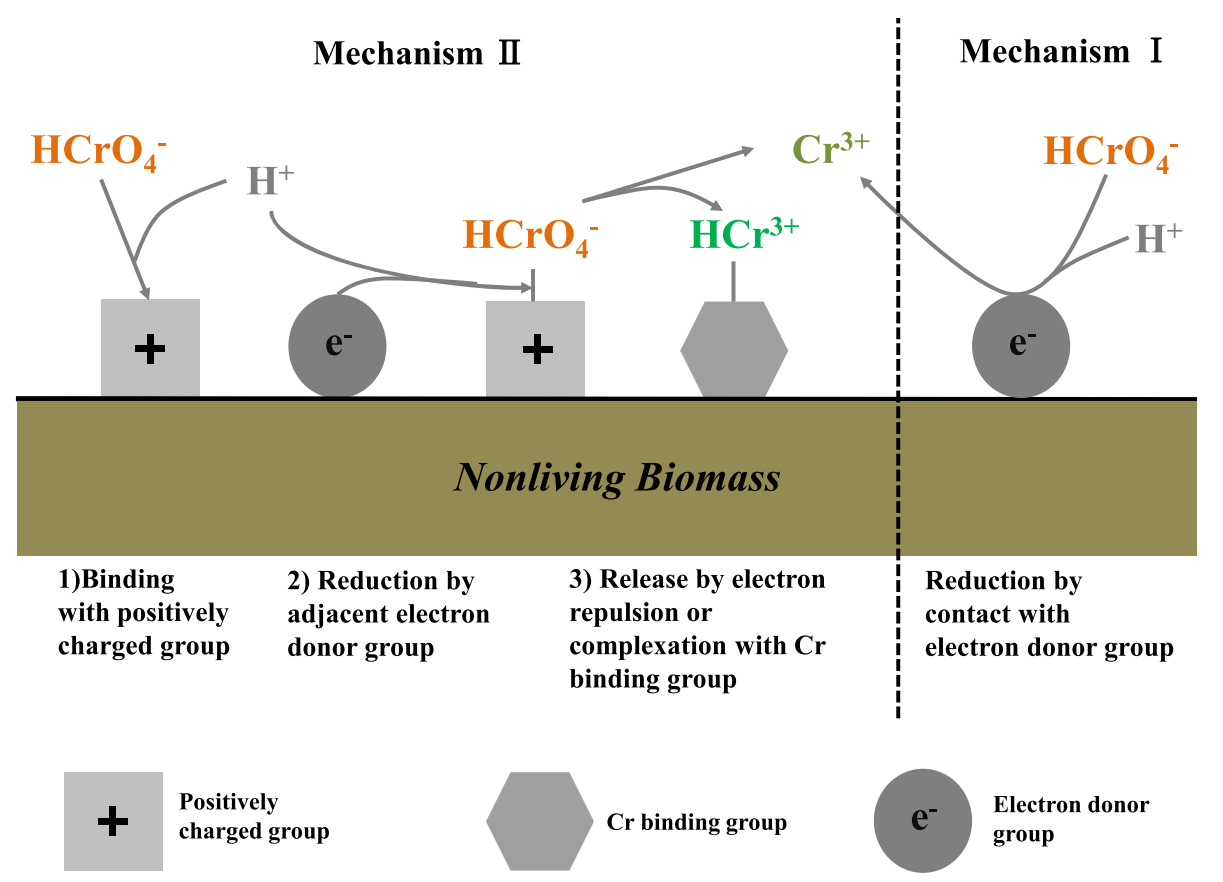

Fig. 2 Proposed mechanism of $\mathrm{Cr}(\mathrm{VI})$ biosorption by nonliving biomaterials 
measuring the $\mathrm{Cr}(\mathrm{VI})$ content of the oxidized and untreated adsorbed supernatants, it was found that the former had a higher $\mathrm{Cr}$ (VI) content. Thus during sorption of $\mathrm{Cr}(\mathrm{VI})$ on the surface of maize bran, there was sorption of $\mathrm{Cr}$ (VI) as well as Cr (III). Namasivayam et al. [31] also verified this mechanism through their experiments.

\section{Adsorbents}

\subsection{Cellulose}

\subsubsection{Characteristics}

Cellulose is the most widely distributed and most abundant polysaccharide in nature, and is one of the main components of plant cell walls. It is a biodegradable, and water insoluble linear polymer composed of $\beta$-Danhydroglucopyranose units, and linked through covalent $\mathrm{C} 1-\mathrm{C} 4 \quad \beta$-glycosidic linkages (Fig. 3). Due to this connection, the properties of the two terminal hydroxyl groups of the cellulose macromolecule are different, with one terminal group being reductive (the glycoside hydroxyl group at $\mathrm{C} 1$ ) and the other terminal group being non-reductive (the hydroxyl group at $\mathrm{C} 4$ ).

Cellulose contains closely and regularly packed crystalline regions along with loosely and randomly packed amorphous regions [32]. The exposed hydroxyl groups on the fine fiber molecular chain form intramolecular/ intermolecular hydrogen bonds under electrostatic action, forcing the fine fiber molecular chains to approach each other, tangling to form both a crystal-like structure and a loose amorphous structure. These two parts are alternately connected to form a bundle of fibers. Compared with the highly ordered crystalline regions, the extent of intramolecular and intermolecular hydrogen bonding in the randomly ordered amorphous regions is lower, so it is more vulnerable to be attacked [33-35].

\subsubsection{Adsorption by native cellulose}

Pyrzynska et al. suggested that the ion-exchange capacity of native cellulose to trace metals is usually very low (generally between 0.01 and $0.05 \mathrm{mmol} / \mathrm{g}$ ) [36]. Many adsorption studies have been carried out with untreated cellulosic materials, such as leaves, roots, shells, barks, husks, stems, and seeds. (Table 1).

Rosa et al. proposed that during adsorption, carboxyl groups were produced by redox reactions between oxygen-containing groups on the bark and $\mathrm{Cr}(\mathrm{VI})$, and these were in turn responsible for the biosorption of $\mathrm{Cr}$ (III) produced by $\mathrm{Cr}$ (VI) reduction [54]. A number of other researchers have experimentally confirmed this mechanism, and it is believed that the $\mathrm{Cr}$ (VI) removal rate is higher at low $\mathrm{pH}$ values because reduction of $\mathrm{Cr}$ (VI) to $\mathrm{Cr}$ (III) is favored at low $\mathrm{pH}$.

Examining Cr (III), Peng et al. [50] reported that the adsorption capacities of metal ions were improved with increasing initial $\mathrm{pH}$ values. Based on this, Omorogie et al. [55] also proposed that the hydroxyl groups were likely the main biosorption site for $\mathrm{Cr}$ (III). Aditya et al. found that biosorption of $\mathrm{Cr}$ (III) from aqueous solution increases significantly with an increase in $\mathrm{pH}$ from 1 to 3 ; beyond this, biosorption capacity reduced as $\mathrm{pH}$ increased. This was because at high $\mathrm{pH}$ precipitation occurred due to the formation of hydroxides, making accurate sorption studies difficult.

\subsubsection{Adsorption by modified cellulose}

Although abundant hydroxyl groups are present in cellulose, its high crystallinity and the strong hydrogen bonds amongst its chains restrict the accessibility of surface hydroxyl groups and limit its practical applications [56]. Because of this, many studies have focused on improving the adsorption capacity of cellulose-based materials through these hydroxyl groups to trigger free radical reactions, esterification, halogenation, oxidation, and etherification [57].

Zhou et al. $[58,59]$ grafted cellulose powder with the vinyl monomer glycidyl methacrylate, and respectively obtained two adsorbents, Cell-g-GMA- $\beta-\mathrm{CDN}^{+}$and

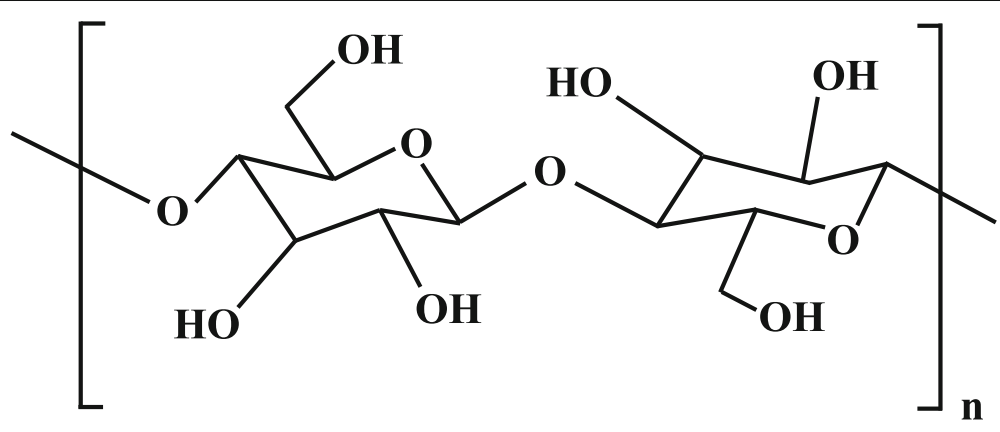

(Cellulose)

Fig. 3 Schematic representation of cellulose structure 
Table $1 \mathrm{pH}$ at maximum adsorption and adsorption capacity of different types of cellulose

\begin{tabular}{|c|c|c|c|c|}
\hline Adsorbent & $\mathrm{pH}$ & $\begin{array}{l}\text { Sorption capacity }[\{(\mathrm{mg} / \mathrm{g})(\mathrm{a})\} \text { or removal } \\
\text { effificiency }(\%)(\mathrm{b})\} \text { or }\{(\mathrm{m} \text { mole/g) }(\mathrm{c})]\end{array}$ & Refs. & Chromium species \\
\hline Camellia oleifera seed shell carbon & 2 & 99.99(b) & {$[37]$} & $\mathrm{Cr}(\mathrm{Vl})$ \\
\hline garlic stem & 2 & $72(b)$ & [38] & $\mathrm{Cr}(\mathrm{Vl})$ \\
\hline horse chesnut shell & & $95(b)$ & & \\
\hline walnut shell & 2 & / & [39] & $\mathrm{Cr}(\mathrm{VI})$ \\
\hline almond shell & 2 & $100(b)$ & [40] & $\mathrm{Cr}(\mathrm{Vl})$ \\
\hline barks of Acacia albida & 2 & $98.47(b)$ & [41] & $\mathrm{Cr}(\mathrm{Vl})$ \\
\hline leaves of Euclea schimperi & 2 & 97.39(b) & & \\
\hline mangrove leaf powder & & $23.75(a)$ & {$[42]$} & $\mathrm{Cr}(\mathrm{Vl})$ \\
\hline tea factory waste & 2 & $54.65(a)$ & [43] & $\mathrm{Cr}(\mathrm{Vl})$ \\
\hline Vigna radiata Husk (Green Gram) & 2 & / & [44] & $\mathrm{Cr}(\mathrm{Vl})$ \\
\hline acorn shell of Quercus crassipes Humb. \& Bonpl. & 3 & 1.9 (c) & [45] & Total $\mathrm{Cr}$ \\
\hline avocado shell & 1.5 & / & [46] & Total $\mathrm{Cr}$ \\
\hline \multirow[t]{2}{*}{ Schinus molle Bark } & / & $97.56(a)$ & {$[47]$} & $\mathrm{Cr}(\mathrm{Vl})$ \\
\hline & & 73.18(a) & & Total $\mathrm{Cr}$ \\
\hline \multirow[t]{2}{*}{ Prunus serotina Bark } & & $93.61(a)$ & [48] & $\mathrm{Cr}(\mathrm{Vl})$ \\
\hline & & 69.93(a) & & \\
\hline \multirow[t]{2}{*}{ PLUM (P. domestica L.) TREE BARK } & $1.0-2.0$ & / & [49] & $\mathrm{Cr}(\mathrm{Vl})$ \\
\hline & 2.0 & & & Total Cr \\
\hline foxtail millet shell & 5 & $11.70(a)$ & [50] & $\mathrm{Cr}(I I I)$ \\
\hline Moringa stenopetala Seed & / & $99.74(b)$ & {$[51]$} & $\mathrm{Cr}(\mathrm{III})$ \\
\hline Erythrina variegata Orientalis leaf & 3 & $1.72(a)$ & [52] & $\mathrm{Cr}(I I I)$ \\
\hline Eugenia jambolana Leaves & 4 & $3.815(\mathrm{a})$ & [53] & $\mathrm{Cr}(\mathrm{III})$ \\
\hline
\end{tabular}

Cell-g-GMA-D-Glu, by deriving with $\beta$-CD and quaternary ammonium groups and D-Glucose (D-Glu). It was found that the maximum adsorption capacity of $\mathrm{Cr}(\mathrm{VI})$ reached $61.05 \mathrm{mg} / \mathrm{g}$ and $54.59 \mathrm{mg} / \mathrm{g}$ for these two compounds, respectively. This is believed to be because the surfaces of the modified adsorbents were rough, and these heterogeneous surfaces could enlarge the specific surface area of the adsorbents to provide more adsorption sites for $\mathrm{Cr}(\mathrm{VI})$.

Peng et al. [60] synthesized the modified cellulose adsorbent MCC-PVIM by crosslinking cellulose and PVIM through etherification and amination, and found that this compound had a maximum adsorption capacity of $\mathrm{Cr}$ (VI) of $134 \mathrm{mg} / \mathrm{g}$. The macropores supported by the cellulose chain are conducive to the diffusion of chromium ions, and the imidazole group provides an active center for the binding of chromium ions. The adsorption mechanism of $\mathrm{Cr}$ (VI) by MCC-PVIM was proposed to be adsorption-coupled reduction.

Liu et al. [61] prepared a cationic adsorbent by modifying a cellulose-based adsorbent with glutamic acid. It was demonstrated that the epoxy and carboxylate groups were linked with the cellulose matrix, which provided suitable adsorption sites for the accessibility of $\mathrm{Cr}$ (III) ions.
In addition to these materials, the macromolecule polyethyleneimine was grafted on porous cellulose particles by He et al. [62] via the introduction of epoxy group and open loop reactions, creating the functional adsorbent of PEI-cell. The saturation adsorption of polyethyleneimine-cellulose was $83.98 \mathrm{mg} / \mathrm{g}$ for Cr (III). They suggested that the adsorption ability of PEI-cell for Cr (III) was good due to hydrogen bond and chelation interactions.

\subsection{Lignin \\ 4.2.1 Characteristics}

Lignin is one of the most abundant natural raw materials available on earth, second only to cellulose in terms of mass [63]. As a major component of wood, it accounts for $23 \sim 33 \%$ of softwood mass and $16 \sim 25 \%$ of hardwood mass [64]. Lignin is a three-dimensional and highly branched polyphenolic substance most commonly found in wood, and is a component of secondary plant cell walls. Lignin fills the space between the cellulose, hemicellulose, and pectin components in the cell wall, giving the cell mechanical strength. Indeed, lignin plays an indispensable role in the binding agglomeration of fibrous cellulosic components and preventing cellulosic 
fibers from being destroyed by microorganisms [65]. As a very complex natural polymer, no precise single structure has been defined. According to reliable reports to date, lignin is possibly composed of three structural units, 4-hydroxy-3,5-dimethoxycinnamyl (sinapyl, S), 4hydroxy-3-methoxycinnamyl (coniferyl, G) alcohol, and 4-hydroxycinnamyl (p-coumaryl, $\mathrm{H}$ ) alcohol, which are linked by various alkyl ether linkages ( $\beta-\mathrm{O}-4$ (most common), 4-O-5 and $\alpha-O-4)$, and $C-C$ linkages ( $\beta-\beta, \beta-1, \beta-5$ and 5-5) [66] (Fig. 4) [67].

\subsubsection{Adsorption by native lignin}

There are two main types of acidic sites on the surface of lignin: carboxyl groups and phenol groups. Deprotonation of these sites may be the dominant mechanism of lignin metal ion adsorption; the affinity of phenol sites to metal ions is higher than that of carboxyl groups [68]. Sciban et al. [69] reported that the adsorption selectivity of alkaline lignin to $\mathrm{Cr}(\mathrm{VI})$ was much higher than $\mathrm{Cd}$ (II), $\mathrm{Cu}$ (II), and $\mathrm{Zn}$ (II).

For the adsorption of Cr (III), Wu's [70] report confirmed the view of the ionic adsorption mechanism. Meanwhile, Yu et al. [71, 72] supposed that Cr (III) ions are adsorbed according to the ion-exchange mechanism for $\mathrm{pH}$-dependent adsorption. As for $\mathrm{Cr}(\mathrm{VI})$, the ionic adsorption mechanism was confirmed by some experiments, which showed the maximal removal efficiency of $\mathrm{Cr}$ (VI) was at $\mathrm{pH} 3$ [73, 74]. Yusof et al. [75] indicated that the $\mathrm{Cr}_{2} \mathrm{O}_{7}{ }^{2-}$ ion needs two adjacent sorption sites on the surface of the biosorbents to bond firmly, and therefore, the adsorption probability of the $\mathrm{Cr}$ (VI) oxoanion decreased. On the other hand, Shen et al. [76] supported the adsorption-coupled reduction mechanism, proposing that the phenolic methoxyl and hydroxyl groups of lignin are the dominant drivers of $\mathrm{Cr}$ (VI) reduction. In this mechanism, the carbonyl and carboxyl groups produced by the redox reaction provide a binding site for $\mathrm{Cr}$ (III) resulting from $\mathrm{Cr}$ (VI) reduction. Further study is needed in order to clarify these mechanisms.

\subsubsection{Adsorption by modified lignin}

Activated carbon has high specific surface area and welldeveloped porosity, and therefore the preparation of activated carbon is an important aspect of lignin-based material modification. Gonzalez et al. [77] used $\mathrm{H}_{3} \mathrm{PO}_{4}$ to impregnate lignin, and confirmed that the best impregnation ratio and activation temperature were $2 \mathrm{~g}$

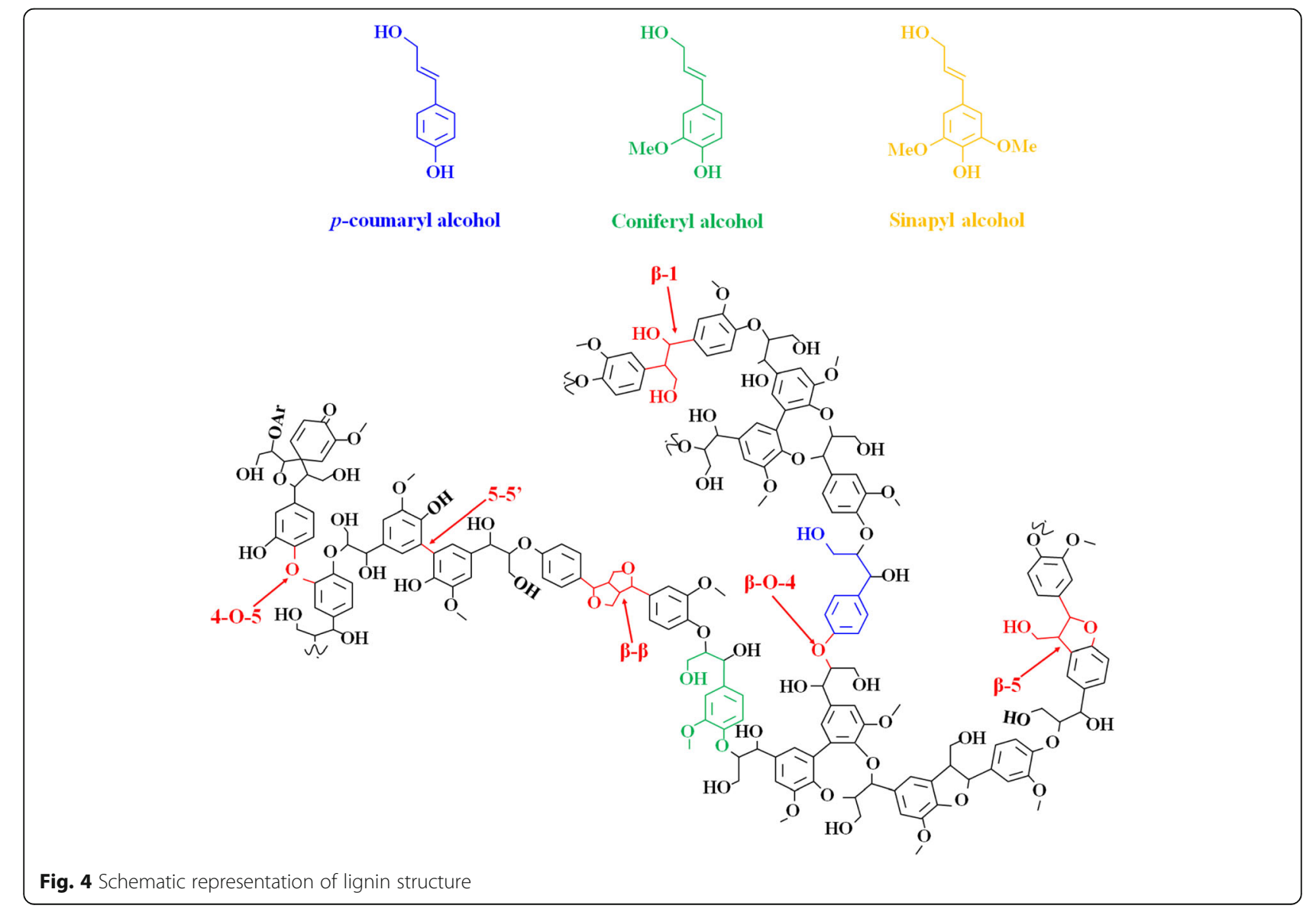


$\mathrm{H}_{3} \mathrm{PO}_{4} / \mathrm{g}$ lignin and $700 \mathrm{~K}$, respectively. Albadarin et al. $[78,79]$ also used $\mathrm{H}_{3} \mathrm{PO}_{4}{ }^{-}$activated lignin for $\mathrm{Cr}(\mathrm{VI})$ adsorption and speculated that chemical modification may occur between the $-\mathrm{OH}$ and $-\mathrm{COOH}$ groups of lignin and the $\mathrm{H}_{3} \mathrm{PO}_{4}$ molecules. The results demonstrated that the adsorption capacity of $\mathrm{Cr}$ (VI) was $77.85 \mathrm{mg} / \mathrm{g}$, which is higher than that of other materials.

Sulfonation of lignin is also an important method to improve its adsorption capacity. Geng et al. [80] fabricated magnetic lignosulfonate (MIS), which exhibited excellent adsorption properties for Cr (VI) $(57.14 \mathrm{mg} / \mathrm{g})$. A variety of chemical substances are also used for lignin modification, such as diethylenetriamine, polyaniline, polyethylenimine, poly (ethylene imine), poly (vinyl alcohol), (2-hydrazinyl-2oxoethyl)-trimethylazanium chloride, and dopamine [81-86]. Kwak et al. [87] fabricated polyethylenimine modified lignin particles with excellent mechanical properties and $\mathrm{Cr}$ (VI) adsorption capacity $(657.9 \mathrm{mg} / \mathrm{g})$, which was attributed to the introduced amine functional groups. Further, they proposed that $\mathrm{Cr}$ (VI) removal with PEI-lignin particles may occur via an adsorption-coupled reduction mechanism.

Other research has focused on lignin-based resins $[88,89]$. Chen et al. investigated lignin-based weakly acidic cation exchange resin (LBR), which showed high adsorption capability for $\mathrm{Cr}(\mathrm{VI})(3.95 \mathrm{mg} / \mathrm{g})$ with a removal rate of $91.9 \%$. They believe that the unique structure and chemical properties of lignin make it suitable for the remediation of $\mathrm{Cr}(\mathrm{VI})$ in the soil.

Nair et al. [90] combined chitosan and lignin into a novel adsorbent for metal ions, which exhibited good mechanical properties and Cr (VI) adsorption capacity. The amine group and the hydroxyl group are the two types of active site in the adsorbent, which are protonated to combine with anionic $\mathrm{HCrO}_{4}^{-}$groups. Compared with pure chitosan, the introduction of lignin greatly reduces the cost of the adsorbent.

\subsection{Tannin}

\subsubsection{Characteristics}

Tannins are secondary metabolites of plants that are polyphenols with molecular weights of $500 \sim 3000$. Tannins in different species have different uses due to their different chemical structures. According to their structural characteristics, they can be divided into three types: hydrolysable tannin, condensed tannin, and complex tannin. Hydrolysable tannin contains gallotannin, which is an ester of glucose or polyols with gallic acid, and ellagitannin, an ester of glucose or polyols formed with ellagic acid and gallic acid. The most important constituent units of condensed tannin are flavan-3-ol and anthocyanidin, such as black wattle tannin and larch bark tannin, which are different from hydrolysable tannins. Complex tannin contains both condensed tannin- like structural features (flavan-3-ol) and hydrolyzed tannin-like tannins (Fig. 5) [91].

The chemical structure and unique chemical properties of polyphenolic hydroxyl groups of tannins make it exhibit a variety of biological activities such as strong antioxidant and antiviral properties. Tannin can react with proteins, polysaccharides, alkaloids, and complex with metal ions. It can be used as bacteriostatic agent, antioxidant, preservative, tanning agent, water treatment agent, and adsorption resin [92].

\subsubsection{Adsorption by native tannin}

In terms of complexing ability with metal ions, hydrolyzed tannin is stronger than condensed tannin, which is stronger than condensed tannin containing catechin structural units, which is stronger than condensed tannin containing gallocatechin structural units. In addition, compared with catechol, the phenolic hydroxyl group of biphenols is more easily dissociated, and therefore has a stronger ability to complex with metal ions. In addition, the review reported by Bacelo et al. [13] demonstrated that the adsorption selectivity of various tannins to $\mathrm{Cr}$ (VI) was generally higher than to $\mathrm{Cu}$ (II), $\mathrm{Zn}$ (II), $\mathrm{Pb}$ (II).

Nakano et al. [93] clarified that the adsorption mechanism of $\mathrm{Cr}$ (VI) to the condensed-tannin gels includes following steps: esterification of chromate with tannin molecules, reduction of $\mathrm{Cr}$ (VI) to $\mathrm{Cr}$ (III), oxidation of tannin molecules to form carboxyl groups, and ion exchange of reduced Cr (III) with carboxyl and hydroxyl groups. Elangovan et al. [94, 95] also confirmed that the removal of $\mathrm{Cr}$ (VI) by tannin follows the adsorptioncoupled reduction mechanism. More specifically, Cr (VI) was adsorbed on the tannin through the esterification of chromate with the catechol group, which means that $\mathrm{Cr}$ (VI) should combine with catechol as a hard acid, the $\mathrm{CrO}_{2}{ }^{2+}$ cation [96].

\subsubsection{Adsorption by modified tannin}

Some modifications are dedicated to fixing tannin on carriers to improve the stability and recyclability of adsorbents. Hassoune et al. [97] used chestnut and quebracho tannins reacted with gelatin to obtain two polymers (GC, GQ), which showed maximum $\mathrm{Cr}$ (VI) absorptions of $80.64 \mathrm{mg} / \mathrm{g}$ and $26.25 \mathrm{mg} / \mathrm{g}$, respectively. Zhang et al. [98] immobilized bayberry tannin (BT) onto chitosan microfiber (CM) to prepare CM-BT adsorbent, which featured a microfibrous morphology and dense adsorption sites, and showed very high selectivity to $\mathrm{Cr}$ (III) from aqueous solution. Huang et al. [99] compounded a tannin-immobilized adsorbent by using mesoporous silica bead as the supporting matrix, and found that the coexisting metal ions in solution had no influence on the adsorption of $\mathrm{Cr}$ (III) onto the $\mathrm{BT}-\mathrm{SiO}_{2}$. Black wattle (BW) tannin was covalently immobilized onto 


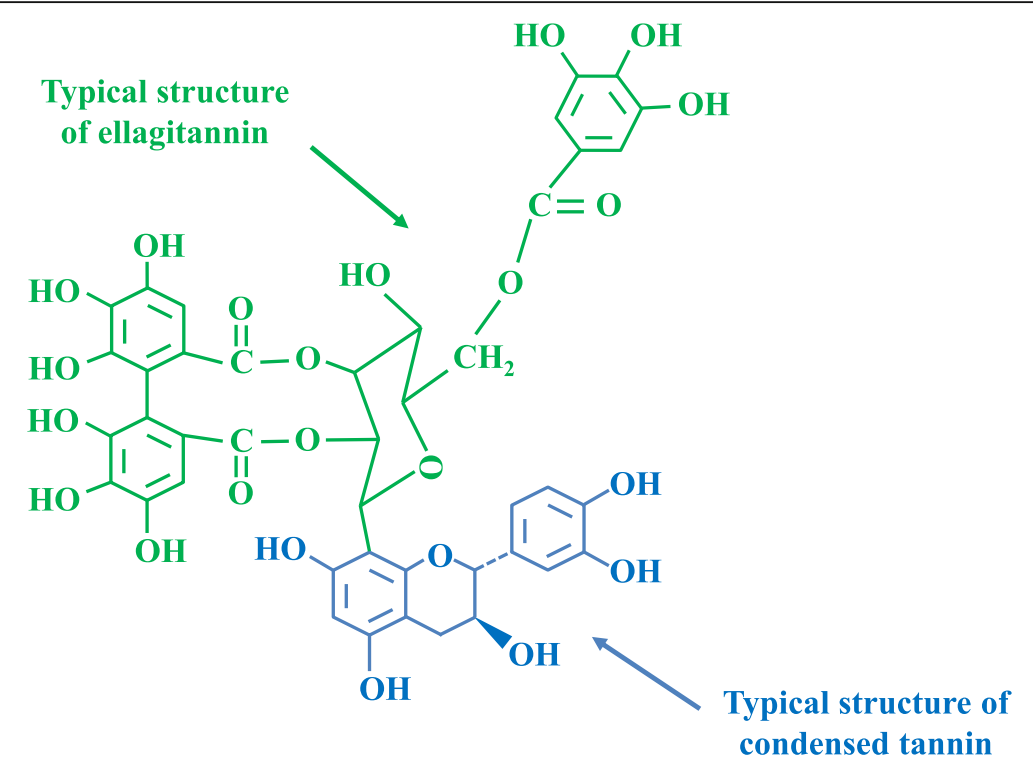

Fig. 5 Schematic representation of a complex tannin structure

dialdehyde nanocellulose (DANC) to obtain a tanninnanocellulose (TNCC) composite by $\mathrm{Xu}$ et al. [100]. They found that the thermal stability of TNCC was slightly increased by the addition of nanocellulose. Li et al. [101] prepared food-grade tannic acid-immobilized powdered activated carbon (TA-PAC). Their results indicated that the immobilization process introduced abundant acid functional groups, and the adsorption capacity of TA-PAC was found to be $\mathrm{pH}$-dependent, with an optimal $\mathrm{pH}$ value of 4.0.

Some modifications increase the adsorption capacity of adsorbents by grafting chemical groups or polymer compounds. A gel (PGA-PL-tannin) with polyglutamic acid ( $\gamma$-PGA), polylysine $(\varepsilon-\mathrm{PL})$ and tannin was prepared to effectively remove $\mathrm{Cr}(\mathrm{VI})$, and was demonstrated to have a removal rate of more than $90 \%$ at $\mathrm{pH} 6 \sim 9$ [102]. Liu et al. [103] studied the effect of the mole ratio of tannin (TA) and hexamethylendiamine (HA) on poly (tannin-hexamethylendiamine) (PTHA) adsorption capacity. When the mole ratio of TA/HA was equal to 1 : 12.5, PTHA exhibited excellent adsorption behavior.

Functional polymer resins are an important aspect of heavy metal adsorbents. Huang et al. [104] prepared Larch tannin resin (LTNA) using a microwave modified cross-linking reaction. There are a large number of pores in the internal structure of the resin, which contribute to the adsorption of $\mathrm{Cr}(\mathrm{VI})$. An optimum adsorption capacity of $9.134 \mathrm{mg} / \mathrm{g}$ was obtained at $\mathrm{pH} 1.0$.

\subsection{Chitin and chitosan}

\subsubsection{Characteristics}

Chitin is widely found in the shells of crustaceans, the crusts of insects, and the cell walls of fungi, as well as in some green algae. It is mainly used to support the skeleton and protect the body. Cellulose, chitin, and chitosan have similar chemical structures. At the $\mathrm{C} 2$ position, cellulose has a hydroxyl group, while in chitin and chitosan this group is replaced by an acetylamino group and an amino group, respectively. Chitin is formed from $2-$ acetamide-2-deoxy-D-glucose through a $\beta-(1-4)$ linkage (Fig. 6) [105].

Chitosan is obtained by deacetylation of chitin heated under alkaline conditions. If the degree of acetylation is below $30 \%$, the polymer is termed chitosan; if it is above this, it is termed chitin [106]. The amino group in the chitosan molecular structure is more reactive than the acetamino group in the chitin molecule, which gives the polysaccharide excellent biological functions and allows it to conduct chemical modification. Because of this, chitosan is considered as a functional biomaterial with greater application potential than cellulose.

\subsubsection{Adsorption by native chitin and chitosan}

The monomer structures of chitin and chitosan have a hydroxyl group on the $\mathrm{C} 3$ position and an acetylamino and amino group at the $\mathrm{C} 2$ position, respectively. Their chemical bonds are equatorial, which enables them to chelate some metal ions with a certain ion radius at a certain $\mathrm{pH}$; this is especially true of chitosan, which shows cationic behavior in acidic media where the protonation of amine groups leads to adsorption of metal anions by ion exchange. Moreover, the summaries made by $\mathrm{Wu}$ et al. [107] indicated that the adsorption selectivity of native chitosan to $\mathrm{Cr}$ (VI) was generally higher than $\mathrm{Cu}$ (II), Zn (II), Ni (II), Cd (II), and Pb (II). 


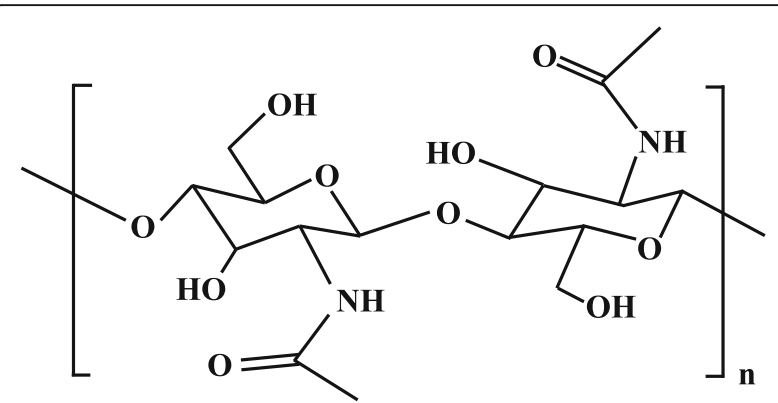

(Chitin)

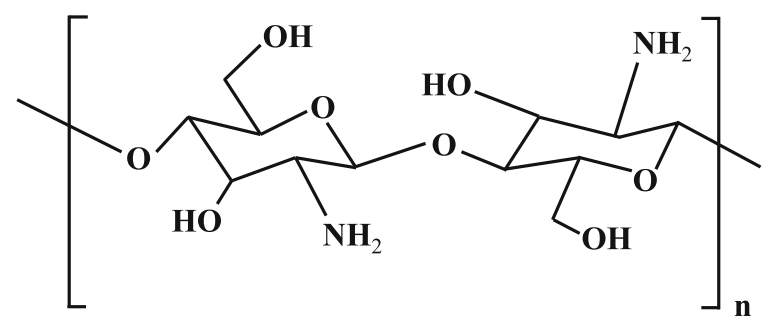

(Chitosan)

Fig. 6 Schematic representation of chitin and chitosan structure

Baran et al. [108] observed that the highest Cr (VI) adsorption capacity of chitosan $(153.83 \mathrm{mg} / \mathrm{g})$ and chitin $(70 \mathrm{mg} / \mathrm{g})$ were both achieved at a $\mathrm{pH}$ of 3.0. The effect of different deacetylation degrees (DD) on adsorption of Cr (VI) by chitosan has also been examined. Santana et al. [109] reported that the DD increase caused an increase in chitosan amino groups and changes in crystallinity were observed, and verified interactions between $\mathrm{Cr}$ (VI) and chitosan-protonated amino groups. As for $\mathrm{Cr}$ (III), Singh et al. [110] reported that both chitin and chitosan gave their best adsorption results at $\mathrm{pH} 3$. However, the adsorption capacity of chitosan to $\mathrm{Cr}$ (III) was higher than that of chitin.

\subsubsection{Adsorption by modified chitin and chitosan}

A few researchers have compared the adsorption capacity of $\mathrm{Cr}(\mathrm{VI})$ on cross-linked and non-cross-linked chitosan. Schmuhl et al. [111] found that the maximum adsorption capacity was found to be $78 \mathrm{mg} / \mathrm{g}$ for noncross-linked chitosan and $50 \mathrm{mg} / \mathrm{g}$ for cross-linked chitosan. Ramnani et al. [112] compared the adsorption behavior of cross-linked chitosan (CRC) and its hydrolysis product $(\mathrm{CRCH})$ with native chitosan $(\mathrm{CH})$, and showed that radiation-cross-linked chitosan had a distinct advantage over chemical cross-linked chitosan. This is because since chemical reagents such as glutraldehyde and epichlorohydrin cause formation of cross-linked chitosan predominantly through the $-\mathrm{NH}_{2}$ group of chitosan, this process results in the loss of $35 \sim 40 \%$ of amino groups
[113], while the amino groups of chitosan are not appreciably affected upon radiation induced crosslinking. They proposed that the most important aspect of using cross-linked chitosan for treating the wastewater containing $\mathrm{Cr}$ (VI) is that the column can be easily regenerated and efficiently reused.

For chemical modification, the amine group at the $\mathrm{C} 2$ position and the hydroxyl groups at the $\mathrm{C} 6$ position are the two main active sites $[114,115]$. Chitin has been grafted with polypyrrole, polyaniline, polyethyleneimine, cinnamaldehyde, and other compounds to improve its ability to adsorb Cr (VI). Karthik Rathinam et al. [116, 117] modified chitin with polypyrrole and polyaniline, and found that the removal of $\mathrm{Cr}(\mathrm{VI})$ by polypyrrole-functionalized chitin (PC) increased with decreasing $\mathrm{pH}$. The removal of $\mathrm{Cr}(\mathrm{VI})$ by the polyaniline-coated chitin (PCC), in contrast, was mainly driven by electrostatic adsorption coupled reduction. Both of the materials could be reused for successive adsorption cycles, which is a far more cost effective treatment strategy. Liang et al. [118] synthesized chitin-based adsorbent $(\mathrm{QCP})$ by cross-linking quaternized chitin and branched polyethylenimine with the aid of epichlorohydrin, which possessed both quaternary ammonium groups and amino groups. In addition, it has been confirmed that the adsorption of $\mathrm{Cr}$ (VI) is carried out by the adsorptioncoupled reduction mechanism. The quaternary ammonium groups and the protonated amino groups combine with the $\mathrm{Cr}$ (VI) anions through electrostatic attractions, following which the $\mathrm{Cr}$ (VI) is partially reduced to $\mathrm{Cr}$ (III) by the amine groups and the hydroxyl groups. Sessarego et al. [119] cross-linked chitosan with tetrakis (hydroxymethyl) phosphonium sulfate (THPS), finding that phosphoniumcrosslinked chitosan (PCC) can be used in wastewater treatment over a wider $\mathrm{pH}$ range than unmodified chitosan. Khalil et al. [120] synthesized two functionalized chitosan nanocomposities, chitosan-cinnamaldehyde (CTS-Cin) and magnetic chitosan nanoparticles (Fe3O4@CTS-Cin), and found that the adsorption of $\mathrm{Cr}$ (VI) onto the CTS-Cin and Fe3O4@CTS-Cin had maximum adsorption capacities of $61.35 \mathrm{mg} / \mathrm{g}$ and $58.14 \mathrm{mg} / \mathrm{g}$, respectively.

Some inorganic ingredients are also used for the modification of chitin and chitosan. Copello et al. prepared a layered silicate-chitosan composite adsorbent by the non-covalent immobilization method, which showed the same retention capacity as chitosan as well as excellent adsorption capacity for Cr (VI) [121]. Zhang et al. [122] synthesized a novel hybrid functionalized chitosan$\mathrm{Al}_{2} \mathrm{O}_{3} @ \mathrm{SiO}_{2}$ composite (FCAS) for the removal of $\mathrm{Cr}$ (VI). Acidic conditions ranging from $\mathrm{pH} 2$ to 6 were conducive to $\mathrm{Cr}$ (VI) adsorption, where an adsorption rate of about $80 \%$ was able to be achieved in only 10 min. Kousalya et al. prepared bio-inorganic composites composed of nano-hydroxyapatite (n-HAp) with chitin and chitosan [123]. The sorption capacities of n-HAp/ 
chitin (n-HApC) composite and n-HAp/chitosan (nHApCs) composite were found to be 2845 and $3450 \mathrm{mg} /$ $\mathrm{kg}$, respectively, which were higher than the individual components. In addition, it was found that the sorption capacities of the composites were slightly influenced by the $\mathrm{pH}$ of the medium and were highly selective in the presence of co-ions. Moreover, these bio-composites are biocompatible, efficient, and biodegradable, making them a promising direction for chromium remediation.

\subsection{Polypeptide}

\subsubsection{Characteristics}

Amino acids containing carboxylate and amine groups make heavy metal chelation possible [124]. The 20 common amino acids each have unique side chains which can serve as effective metal binding sites [125]. For instance, the thiol group of cysteine, the imidazole group of histidine, and the carboxylate group of aspartate and glutamate provide metal binding sites in proteins [126, 127] (Fig. 7) [128]. These groups along with other amino acid side-chain groups form a microenvironment around the metal center where non-covalent or weak interactions can be observed, such as hydrogen bonding, cation- $\pi$ interactions, or hydrophobic interactions [129]. Many experiments have confirmed the effective adsorption of these amino acid-modified adsorbents on chromium, demonstrating that polypeptides made of amino acids are natural biopolymers that can complexate heavy metal ions [130-135]. Economically, keratin and metallothionein are ideal natural chelating agents for heavy metals due to their availability and cost.

\subsubsection{Keratin}

Keratin is a type of fibrous protein which is rich in cysteine residues and has abundant disulfide bonds. It consists of parallel polypeptide chains in both $\alpha$-helical and $\beta$-sheet conformation, and is predominantly present in feathers, animal claws and horns, wool, fingernails, and hair [136]. Keratin is usually discarded as waste in various industrial processes. However, a large number of studies have demonstrated that keratin is a kind of natural biodegradable polymer with good mechanical properties, and have indicated that it also shows good application prospects for the adsorption of chromium.

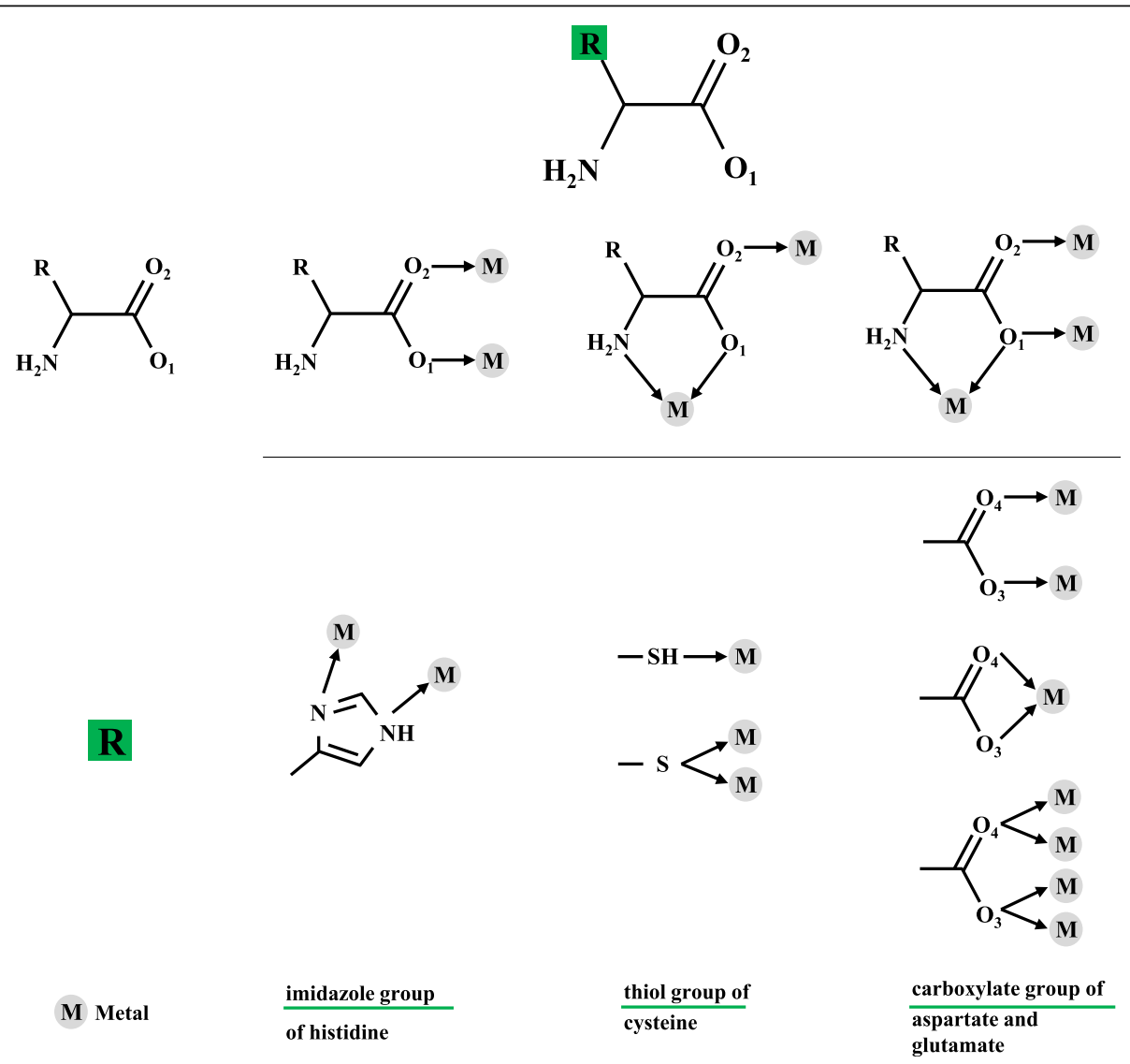

Fig. 7 Schematic representation of the common skeleton of a amino acid (top), the potential coordination modes between the skeleton and a metal (middle) and the potential coordination modes between the side chains and a metal (bottom) 
Zhang et al. [137] compared the ability of four common waste keratin biofibers (human hair, dog hair, chicken feathers, and degreased wool) to absorb heavy metal ions from aqueous solutions. The results showed that for multiple-metal systems consisting of a mixture of eight metal ions [Cr (III), Mn (II), Co (II), Ni (II), Cu (II), $\mathrm{Zn}$ (II), Cd (II), and $\mathrm{Pb}$ (II)], the total metal biosorption capacity of the keratin sources was degreased wool $>$ chicken feathers $>$ human hair $>$ dog hair. They proposed that the keratin biofibers from wool and chicken feathers were the more efficient sorbents of metal ions. Further, Zhuang et al. [138] studied Cr (VI) adsorption on a thermoplastic feather keratin film. It was found that the best absorption capacity was $75.45 \mathrm{mg} / \mathrm{g}$ at $60^{\circ} \mathrm{C}$. Gao et al. [139] used deposits produced from chicken feathers after soluble keratin extraction for Cr (VI) adsorption, observing that the monolayer biosorption capacity for Cr (VI) was $21.35 \mathrm{mg} / \mathrm{g}$ at pH 6 with a $200 \mathrm{mg} /$ $\mathrm{L}$ initial concentration of $\mathrm{Cr}(\mathrm{VI})$ ions and at $30^{\circ} \mathrm{C}$. Mondal et al. [140] examined the potential of human hair for removal of $\mathrm{Cr}$ (VI) from aqueous solutions, and revealed that its maximum adsorption capacity of $\mathrm{Cr}$ (VI) was $9.852 \mathrm{mg} / \mathrm{g}$ at $\mathrm{pH} 1.0$.

Furthermore, a number of researchers have focused on the study of keratin-modified materials. Branisa et al. [141] investigated the adsorption of Cr (III) on sheep wool irradiated by an electron beam. It was confirmed that the amino and hydroxyl ligands provided by different chains were prerequisites for the formation of crosslinks, and that the chemisorption of $\mathrm{Cr}$ (III) is related to the formation of complex chromate based on carboxylates and cysteinates. Saucedo et al. [142] used a porous polyurethane-keratin hybrid membrane to remove $\mathrm{Cr}$ (VI). Fourier-transform infrared analysis suggested that the $\mathrm{NH}, \mathrm{C}=\mathrm{O}, \mathrm{S}-\mathrm{S}$, and $\mathrm{C}-\mathrm{S}$ functional groups of keratin participated in the linking sorption of $\mathrm{Cr}(\mathrm{VI})$. Since the $\mathrm{pH}$ of the keratin solution above the isoelectric point resulted in higher adsorption of heavy metals, and lower $\mathrm{pH}$ caused lower adsorptions, they indicated that the isoelectric point of keratin was related to the adsorption process. Aluigi et al. [143] prepared hydrolyzed keratin/ polyamide six blend nanofibres for the adsorption of $\mathrm{Cr}$ (VI), and found the maximum adsorption capacity was $55.9 \mathrm{mg} / \mathrm{g}$ at acidic $\mathrm{pH}$.

\subsubsection{Metallothioneins}

Metallothioneins are a group of cysteine-rich molecules, containing a sequential and unique distribution of amino acids (such as Cys-Xaa-Cys, Cys-Xaa-Xaa-Cys, and CysCys motifs, where Xaa represents another amino acid) $[144,145]$. In their reduced state, they provide thiols for metal chelation [146]. A large number of researchers have examined the binding mechanism of these proteins to divalent heavy metals such as $\mathrm{Cd}, \mathrm{Cu}, \mathrm{Hg}$, and $\mathrm{Zn}$
[147-149]. Despite this, in terms of chromium adsorption, there are few related studies. Zhang et al. [150] reported recombinant Saccharomyces cerevisiae expressing metallothionein was able to effectively remove $\mathrm{Cr}$ (VI) from solution. However, it remains to be seen whether there is a metallothionein which can chelate with chromium.

\section{Conclusions}

Cellulose, lignin, tannin, chitin, chitosan, and polypeptide exist in large quantities in nature, and have been extensively studied as adsorbents due to their availability, low cost, and the ability to recycle the heavy metals bound to these polymers. The presence of hydroxyl groups on cellulose, phenolic hydroxyl, methoxyl, and carbonyl groups on lignin, phenolic groups on tannin, amino groups on chitosan, and various functional groups on amino acid side chains leads to the adsorption capacity for chromium to these materials. A large number of investigations have indicated that the adsorption capacity of these adsorbents for chromium is affected by a series of factors such as $\mathrm{pH}$, temperature, amount of adsorbent, adsorption time, the concentration of chromium, and the presence of other metal ions. Due to the influence of the $\mathrm{pH}$ value in adsorption, comparing the IR spectrum of the adsorbents before and after the adsorption, the protonation and deprotonation processes of the functional groups have been analyzed to infer the mechanism of chromium adsorption, providing a possible basis for the study of adsorption mechanism of chromium. In order to improve the adsorption capacity, it has been found that it is imperative to modify these biopolymers; these modifications include activated carbon preparation, resin preparation, chemical modification, the introduction of inorganic compounds, combined application of nanomaterials, and other approaches. Modification not only improves the chromium adsorption capacity of the material, but also enhances the mechanical strength and recyclability of the adsorbent, enabling it to be used in site-based and large-scale practical applications. Although many researchers have tried to demonstrate the mechanism of chromium adsorption, the exact binding mechanism between the functional groups and metal ions is not clear due to the generally high molecular weight and complex structure of these biopolymers. Thus, further research is needed to determine the exact mechanism of this interaction. By optimizing the influencing parameters of different adsorbents and applying advanced chemical modification technologyies, researchers have continuously developed alternatives to commercial adsorbents, to achieve practical application of laboratory-scale novel materials with advantages over the materials currently used. 


\section{Acknowledgements}

This work supported by the Opening Project of Key Laboratory of Leather Chemistry and Engineering, (Sichuan University), Ministry of Education.

\section{Authors' contributions}

Conceived and designed the review, and critical revised the manuscript: YQT; Wrote and revised the manuscript: RSZ. All authors read and approved the final manuscript.

\section{Funding}

We are grateful for the financial support by the National Key Research and Development Program of China (2018YFC1802201).

\section{Availability of data and materials}

The datasets analyzed during the current review are available in the references, which have been specified in the article.

\section{Competing interests}

The authors declare that they have no competing interests.

Received: 1 April 2020 Accepted: 20 August 2020

Published online: 30 August 2020

\section{References}

1. Sarin V, Sarvinder Singh T, Pant KK. Thermodynamic and breakthrough column studies for the selective sorption of chromium from industrial effluent on activated eucalyptus bark. Bioresour Technol. 2006;97(16):1986-93.

2. Bidyut $\mathrm{S}$, Chris $\mathrm{O}$. Biosorbents for hexavalent chromium elimination from industrial and municipal effluents. Coordin Chem Rev. 2010;254:2959-72.

3. Lilli MA, Moraetis D, Nikolaidis NP, et al. Characterization and mobility of geogenic chromium in soils and river bed sediments of Asopos basin. J Hazard Mater. 2015;281(SI):12-9.

4. Ministry of Ecology and Environment of the People's Republic of China. Soil environmental quality Agricultural land soil pollution risk control standards (trial) (GB 15618-2018). http://www.mee.gov.cn/404/index.shtml. Accessed 28 Jun 2018.

5. Shannon MA, Bohn PW, Elimelech M, Georgiadis JG, Marinas BJ, Mayes AM. Science and technology for water purification in the coming decades. Nature. 2008;452(7185):301-10

6. Bhattacharyya KG, Sen GS. Adsorption of a few heavy metals on natural and modified kaolinite and montmorillonite: a review. Adv Colloid Interf Sci. 2008;140(2):114-31.

7. Barakat MA. New trends in removing heavy metals from industrial wastewater. Arab J Chem. 2011:4:361-77.

8. Vusumzi $\mathrm{P}$, Luke C. Polymeric sorbents for removal of $\mathrm{Cr}(\mathrm{VI})$ from environmental samples. Pure App Chem. Maputo, MOZAMBIQUE. 2013; 85(12):2145-60.

9. George VA, Annie PS, Latha MS. Remediation of heavy metals and dyes from wastewater using cellulose-based adsorbents. Environ Chem Lett. 2019;17(2):867-77.

10. Lalvani SB, Hubner A, Witowski TS. Chromium adsorption by lignin. Energy Sources. 2000;22(1):45-56.

11. Yin CY. Emerging usage of plant-based coagulants for water and wastewater treatment. Process Biochem. 2010:45(9):1437-44.

12. Crini G. Non-conventional low-cost adsorbents for dye removal: a review. Bioresour Technol. 2006;97(9):1061-85.

13. Bacelo Hugo AM, Santos Silvia CR, Botelho Cidalia MS. Tannin-based biosorbents for environmental applications - a review. Chem Eng J. 2016; 303:575-87.

14. Landrot G, Tappero R, Webb SM, et al. Arsenic and chromium speciation in an urban contaminated soil. Chemosphere. 2012;88(10):1196-201.

15. Barrera-Díaz CE, Lugo-Lugo V, Bilyeu B. A review of chemical, electrochemical and biological methods for aqueous $\mathrm{Cr}(\mathrm{VI})$ reduction. J Hazard Mater. 2012;223:1-12.

16. Kaufaman DB. Acute potassium dichromate poisoning-treated by peritoneal dialysis. Am J Dis Child. 1970;119(4):374-81.

17. Browning E. Chromium in toxicity of industrial metals, seconded. London: Butterworths and Co; 1969. p. 76-96.

18. Pechova A, Pavlata L. Chromium as an essential nutrient: a review. Vet MedCzech. 2007;52(1):1-18.
19. Arslan P, Beltrame M, Tomasi A. Intracellular chromium reduction. Biochim Biophys Acta. 1987;931(1):10-5.

20. Kadiiska M, Xiang Q, Mason R. In vivo free radical generation by chromium (VI): an Electron spin resonance spin-trapping investigation. Chem Res Toxicol. 1994;7(6):800-5.

21. Liu K, Jiang J, Shi $X$, et al. Low-frequency EPR study of chromium(V) formation from chromium (VI) in living plants. Biochem Biophys Res Commun. 1995;206(3):829-34.

22. Shruti S, Punita U, Khos MA. Overview of wastewater treatment methods with special focus on iopolymer chitin-chitosan. Int J Biol Macromol. 2019; 121:1086-100.

23. Ofomaja AE, Ho YS. Effect of $\mathrm{pH}$ on cadmium biosorption by coconut copra meal. J Hazard Mater. 2007:139(2):356-62.

24. Parvathi K, Nagendra R, Nareshkumar R. Lead biosorption on waste beer yeast by-product, a means to decontaminate effluent generated from battery manufacturing industries. Electron J Biotechnol. 2007;10:1-14.

25. Pino GH, Mesquita LMS, Torem ML, Pinto GAS. Biosorption of cadmium by green coconut shell powder. Miner Eng. 2006;19(5):380-7.

26. Park D, Park JM, Yun YS. Mechanisms of the removal of hexavalent chromium by biomaterials or biomaterial-based activated carbons. J Hazard Mater. 2006:137(2):1254-7.

27. Park D, Yun YS, Kim JY, Park JM. How to study $\mathrm{Cr}(\mathrm{VI})$ biosorption: use of fermentation waste for detoxifying $\mathrm{Cr}(\mathrm{VI})$ in aqueous solution. Chem Eng J. 2008;136:173-9.

28. Park D, Yun YS, Park JM. Studies on hexavalent chromium biosorption by chemically-treated biomass of Ecklonia sp. Chemosphere. 2005;60(10):1356-64.

29. Park D, Park JM, Yun YS. Mechanisms of the removal of hexavalentchromium by biomaterials or biomaterial-based activated carbons. J Hazard Mater. 2006;137(2):1254-7.

30. Hasan SH, Singh KK, Prakash O, Talat M, Ho YS. Removal of Cr (VI) from aqueous solutions using agricultural waste 'maize bran'. J Hazard Mater. 2008;152(1):356-65.

31. Namasivayam C, Sureshkumar MV. Removal of chromium (VI) from water and wastewater using surfactant modified coconut coir pith as a biosorbent. Bioresour Technol. 2008;99(7):2218-25.

32. Park S, Baker JO, Himmel ME, Parilla PA, Johnson DK. Cellulose crystallinity index: measurement techniques and their impact on interpreting cellulase performance. Biotechnol Biofuels. 2010;3(10). https://doi.org/10.1186/17546834-3-10.

33. Cowling EB. Physical and chemical constraints in the hydrolysis of cellulose and lignocellulosic materials. Biotechnol Bioeng Symp. 1975;5:163-81.

34. Gharpuray MM, Lee YH, Fan LT. Structural modification of lignocellulosics by pretreatments to enhance enzymatic hydrolysis. Biotechnol Bioeng. 1983; 25(1):157-72.

35. Zhao H, Kwak JH, Conrad ZZ, Brown HM, Arey BW, Holladay JE. Studying cellulose fiber structure by SEM, XRD, NMR and acid hydrolysis. Carbohydr Polym. 2007;68(2):235-41.

36. Anirudhan TS, Senan P. Adsorption characteristics of cytochrome C onto cationic Langmuir monolayers of sulfonated poly (glycidylmethacrylate)grafted cellulose: mass transfer analysis, isotherm modeling and thermodynamics. Chem Eng J. 2011;168(2):678-90.

37. Guo H, Chenyang B, Chuncheng Z. Camellia oleifera seed shell carbon as an efficient renewable bio-adsorbent for the adsorption removal of hexavalent chromium and methylene blue from aqueous solution. J Mol Liq. 2018;249: $629-36$

38. Serife P, Erol P. Natural biosorbents (garlic stem and horse chesnut shell) for removal of chromium (VI) from aqueous solutions. Environ Monit Assess. 2015;187(12):736.

39. Nethaji S, Sivasamy A. Removal of hexavalent chromium from aqueous solution using activated carbon prepared from walnut shell biomass through alkali impregnation processes. Clean Techn Environ Policy. 2014; 16(2):361-8

40. Rai MK, Giri BS, Nath Y. Adsorption of hexavalent chromium from aqueous solution by activated carbon prepared from almond shell: kinetics, equilibrium and thermodynamics study. J Water Supply Res T. 2018;67(8):724-37.

41. Gebrehawaria G, Hussen A, Rao VM. Removal of hexavalent chromium from aqueous solutions using barks of Acacia albida and leaves of Euclea schimperi. Int J Environ Sci Technol. 2015;12(5):1569-80.

42. Thadikamala S, Vinithkumar NV, Dharani G. Efficacy of mangrove leaf powder for bioremediation of chromium (VI) from aqueous solutions: kinetic and thermodynamic evaluation. Appl Water Sci. 2015;5(2):153-60. 
43. Malkoc E, Nuhoglu Y. Potential of tea factory waste for chromium (VI) removal from aqueous solutions: thermodynamic and kinetic studies. Sep Purif Technol. 2007;54(3):291-8.

44. Saravanakumar K, Kumar A. Removal of hexavalent chromium from aqueous solution using Vigna Radiata husk (green gram). Asian J Chem. 2011;23(6): 2635-8.

45. Erick A-G, Liliana M-B, Gabriela P-C. Effect of pH, ionic strength, and background electrolytes on $\mathrm{Cr}(\mathrm{VI})$ and total chromium removal by acorn shell of Quercus crassipes Humb. \& Bonpl. Environ Monit Assess. 2014; 186(10):6207-21

46. Erick $\mathrm{A}-\mathrm{G}$, Eliseo $\mathrm{C}-\mathrm{U}$. Effect of $\mathrm{pH}$ on hexavalent and total chromium removal from aqueous solutions by avocado shell using batch and continuous systems. Environ Sci Pollut Res. 2019;26(4):3157-73.

47. Alma RN-M, Erick A-G, del Maria CC-U. Removal of hexavalent and total chromium from aqueous solutions BY Schinus molle bark. Fresenius Environ Bull. 2010;19(12):2911-8.

48. Alma RN-M, Liliana M-B, del Maria CC-U. Hexavalent chromium reduction and chromium biosorption by Prunus serotina bark. Fresenius Environ Bull. 2012;21(7):1793-801

49. Perla VL-N, Erick A-G, del Maria CC-U. Removal of Hexavalent and Total Chromium from Aqueous Solutions by Plum(P. domestica L.) Tree Bark. Environ Eng Manag J. 2014;13(8):1927-38.

50. Peng SH, Wang R, Yang LZ. Biosorption of copper, zinc, cadmium and chromium ions from aqueous solution by natural foxtail millet shell. Ecotox Environ Safe. 2018;165:61-9.

51. Degefu DM, Mekibib D. Chromium Removal from Modjo Tannery Wastewater Using Moringa stenopetala Seed Powder as an Adsorbent. Water Air Soil Pollut. 2013;224(12). https://doi.org/10.1007/s11270-013-1719-6.

52. Vamsi AGV, Padma PB, Chitti BN. Biosorption of chromium onto Erythrina Variegata Orientalis leaf powder. Korean J Chem Eng. 2012;29(1):64-71.

53. Rabia R, Jamil A, Tariq M. Adsorptive elimination of chromium (III) and nickel (II) from water by spent Eugenia jambolana leaves: isothermal and Thermodynamical studies. Asian J Chem. 2014;26(3):644-8.

54. Alma RN-M, de Flor MG-J, Benjamin C-G. Kinetic study of the effect of pH on hexavalent and trivalent chromium removal from aqueous solution by Cupressus lusitanica bark. Water Air Soil Pollut. 2012;223(2):625-41.

55. Omorogie Martins O, Babalola Jonathan O, Unuabonah El. Efficient chromium abstraction from aqueous solution using a low-cost biosorbent: Nauclea diderrichii seed biomass waste. J Saudi Chem Soc. 2016;20(1):49-57.

56. Melo BC, Paulino FAA, Cardoso VA, Pereira AGB, Fajardo AR, Rodrigues FHA. Cellulose nanowhiskers improve the methylene blue adsorption capacity of chitosan-g-poly (acrylic acid) hydrogel. Carbohydr Polym. 2018;181:358-67.

57. O'Connell DW, Birkinshaw C, O'Dwyer TF. Heavy metal adsorbents prepared from the modification of cellulose: a review. Bioresour Technol. 2008;99(15): 6709-24.

58. Yanmei Z, Qiang J, Zhu T, Akama Y. Adsorption of chromium (VI) from aqueous solutions by cellulose modified with beta-CD and quaternary ammonium groups. J Hazard Mater. 2011;187(1-3):303-10.

59. Yanmei Z, Oiang J, Zhu T, Ma T, Hu X. Removal of chromium (VI) from aqueous solution by cellulose modified with D-glucose. Sep Sci Technol. 2012:47(1):157-65.

60. Xiong $\mathrm{P}$, Zongcheng $Y$, Hu L, Rongze Z, Shujun L, Aili W, Xiwen Y, Li C. Adsorption behavior of hexavalent chromium in aqueous solution by polyvinylimidazole modifified cellulose. Int J Biol Macromol. 2020;155:118493. https://doi.org/10.1016/j.ijbiomac.2019.11.086.

61. Jing L, Min Y, Yong-Kui Z, Kai-Feng D. Study of glutamate-modified cellulose beads for $\mathrm{Cr}$ (III) adsorption by response surface methodology. Ind Eng Chem Res. 2011;50(18):10784-91.

62. He Z, Hang S, Yannan C. Porous spherical cellulose Carrier modified with Polyethyleneimine and its adsorption for $\mathrm{Cr}$ (III) and Fe (III) from aqueous solutions. Chin J Chem Eng. 2014;22(9):984-90.

63. Gosselink RJA, de Jong E, Guran B. Co-ordination network for lignin-standardisation, production and applications adapted to market requirements (EUROLIGNIN). Ind Crop Prod. 2004;20(2):121-9.

64. Mohan D, Pittman CU Jr, Steele P. Pyrolysis of wood/biomass for bio-oil: a critical review. Energ Fuel. 2006;20(2):848-89.

65. Mohan D, Pittman C. Activated carbons and low cost adsorbents for remediation of tri-and hexavalent chromium from water. J Hazard Mater. 2006;137(2):762-811.

66. Yuanyuan G, Zhili L. Application of lignin and its derivatives in adsorption of heavy metal ions in water: a review. ACS Sustain Chem Eng. 2018;6(5):7181-92.
67. Zakzeski J, Bruijnincx PCA, Jongerius AL, Weckhuysen BM. The catalytic valorization of lignin for the production of renewable chemicals. Chem Rev. 2010;110(6):3552-99.

68. Guo X, Zhang S, Shan X. Adsorption of metal ions on lignin. J Hazard Mater. 2008;151(1):134-42.

69. Sciban MB, Klasnja MT, Antov MG. Study of the biosorption of different heavy metal ions onto Kraft lignin. Ecol Eng. 2011;37(12):2092-5.

70. Wu Y, Zhang S, Guo X, Huang H. Adsorption of chromium (III) on lignin. Bioresour Technol. 2008;99(16):7709-15.

71. Yu LJ, Shukla SS, Dorris KL, Shukla A, Margrave JL. Adsorption of chromium from aqueous solutions by maple sawdust. J Hazard Mater. 2003;100:53-63.

72. Rengaraj S, Joo CK, Kim Y, Yi J. Kinetics of removal of chromium from water and electronic process wastewater by ion exchange resins $1200 \mathrm{H}, 1500 \mathrm{H}$ and IRN97H. J Hazard Mater. 2003;102:257-75.

73. Tazerouti N, Amrani M. Chromium (VI) Adsorption on Activated Lignin. Chemical Product and Process Modeling. 2009;4(1). https://doi.org/10.2202/ 1934-2659.1339.

74. Celik A, Dost K, Sezer H. An investigation of chromium (VI) ion removal from wastewaters by adsorption on residual lignin. Fresenius Environ Bull. 2004; 13(2):124-7

75. Yusof $\mathrm{AM}$, Malek NANN. Removal of $\mathrm{Cr}(\mathrm{VI})$ and as $(\mathrm{V})$ from aqueous solutions by HDTMA-modified zeolite Y. J Hazard Mater. 2009;162:1019-24.

76. Shen Y-S, Wang S-L, Shiuh-Tsuen H. Biosorption of $\mathrm{Cr}(\mathrm{VI})$ by coconut coir: spectroscopic investigation on the reaction mechanism of $\mathrm{Cr}(\mathrm{VI})$ with lignocellulosic material. J Hazard Mater. 2010;179:160-5.

77. Gonzalez-Serrano E, Cordero T, Rodriguez-Mirasol J. Removal of water pollutants with activated carbons prepared from H3PO4 activation of lignin from Kraft black liquors. Water Res. 2004;38(13):3043-50.

78. Albadarin AB, Mangwandi C, Al-Muhtaseb AH, Walker GM, Allen SJ, Ahmad MNM. Modelling and fixed bed column adsorption of $\mathrm{Cr}(\mathrm{VI})$ onto Orthophosphoric acid-activated lignin. Chin J Chem Eng. 2012;20(3):469-77.

79. Albadarin AB, Al-Muhtaseb AH, Walker GM, Allen SJ, Ahmad MNM. Retention of toxic chromium from aqueous phase by H3PO4-activated lignin: effect of salts and desorption studies. Desalination. 2011;274:64-73.

80. Jing $G$, Fei $G$, Jianmin C. Fabrication of magnetic lignosulfonate using ultrasonic-assisted in situ synthesis for efficient removal of $\mathrm{Cr}(\mathrm{VI})$ and Rhodamine B from wastewater. J Hazard Mater. 2019;375:174-81.

81. Zhanxin S, Wei L, Wentao L. Novel magnetic lignin composite sorbent for chromium (VI) adsorption. RSC Adv. 2015;5(17):13028-35.

82. Ho SJ, Soon CC, Ho BJ. Preparation of a lignin/Polyaniline composite and its application in $\mathrm{Cr}(\mathrm{VI})$ removal from aqueous solutions. Bioresources. 2019; 14(4):9169-82

83. Popovic Ana L, Rusmirovic Jelena D, Zlate V. Novel amino-functionalized lignin microspheres: High performance biosorbent with enhanced capacity for heavy metal ion removal. Int J Biol Macromol. 2019;156:1160-73. https:// doi.org/10.1016/j.ijbiomac.2019.11.152.

84. Won KH, Heechang W, Hwa KE. Water-resistant lignin/poly (vinyl alcohol) blend fibers for removal of hexavalent chromium. Fiber Polym. 2018;19(6): $1175-83$.

85. Wang Z, Wenxiu H, Pingping B. Preparation of quaternary amine-grafted organosolv lignin biosorbent and its application in the treatment of hexavalent chromium polluted water. Int J Biol Macromol. 2019;126:1014-22.

86. Lin D, Yuantao L, Rui L. Green mussel-inspired lignin magnetic nanoparticles with high adsorptive capacity and environmental friendliness for chromium (III) removal. Int J Biol Macromol. 2019:132:478-86.

87. Won KH, Hyunji L, Hoon LK. Surface-modified spherical lignin particles with superior Cr (VI) removal efficiency. Chemosphere. 2020;239. https://doi.org/ 10.1016/j.chemosphere.2019.124733.

88. Liang F-B, Yan-Lei S, Chong-Pin H. Synthesis of novel lignin-based ionexchange resin and its utilization in heavy metals removal. Ind Eng Chem Res. 2013;52(3):1267-74.

89. Nawei C, Guo Q, Chongpin H. Removal of hexavalent chromium in soil by lignin-based weakly acidic cation exchange resin. Chin J Chem Eng. 2019; 27(10):2544-50.

90. Vaishakh N, Ajitesh P. Vinu R. development of novel chitosan-lignin composites for adsorption of dyes and metal ions from wastewater. Chem Eng J. 2014;254:491-502.

91. Hatano T, Shida S, Han L. Camelliatannins A and B, Two New Complex Tannins from Camellia japonica L. Chem Pharm Bull. 1991;39(4):876-80.

92. Shi B, et al. Plant polyphenol. Beijing: The Science Publishing Company; 2000. p. 5. 
93. Nakano Y, Takeshita K, Tsutsumi T. Adsorption mechanism of hexavalent chromium by redox within condensed-tannin gel. Water Res. 2001;35(2): 496-500.

94. Nakajima A, Baba Y. Mechanism of hexavalent chromium adsorption by persimmon tannin gel. Water Res. 2004;38(12):2859-64.

95. Elangovan R, Ligy $\mathrm{P}$, Chandraraj K. Biosorption of hexavalent and trivalent chromium by palm flower (Borassus aethiopum). Chem Eng J. 2008;141:99-111.

96. Elangovan R, Ligy P, Chandraraj K. Biosorption of chromium species by aquatic weeds: kinetics and mechanism studies. J Hazard Mater. 2008;152(1):100-12.

97. Hassoune J, Tahiri S, El Krati M. Removal of Hexavalent Chromium from Aqueous Solutions Using Biopolymers. J Environ Eng. 2018;144(8). https:// doi.org/10.1061/(ASCE)EE.1943-7870.0001396.

98. Ting Z, Wang Y, Yiwen K. Adsorptive removal of $\mathrm{Cr}^{3+}$ from aqueous solutions using chitosan microfibers immobilized with plant polyphenols as biosorbents with high capacity and selectivity. Appl Surf Sci. 2017;404:418-25.

99. Xin H, Liao X, Bi S. Tannin-immobilized mesoporous silica bead (BT-SiO2) as an effective adsorbent of $\mathrm{Cr}$ (III) in aqueous solutions. J Hazard Mater. 2010;173:33-9.

100. Xu Q, Wang Y, Liqiang J. Adsorption of $\mathrm{Cu}(\mathrm{II}), \mathrm{Pb}(\mathrm{II})$ and $\mathrm{Cr}(\mathrm{VI})$ from aqueous solutions using black wattle tannin-immobilized nanocellulose. J Hazard Mater. 2017;339:91-9.

101. Weiguang $L$, Xujin $\mathrm{G}$, Xin L. Removal of $\mathrm{Cr}(\mathrm{VI})$ from low-temperature micropolluted surface water by tannic acid immobilized powdered activated carbon. Bioresour Technol. 2012:113(SI):106-13.

102. Haisong Y, Guangming L, Xin Q. Removing $\mathrm{Cr}(\mathrm{Vl})$ from aqueous solutions via absorption by green synthesized PGA-PL-tannin gel. Pol J Environ Stud. 2020;29(2):1973-80.

103. Qiang L, Qinze L, Bingsi L. Green synthesis of tannin-hexamethylendiamine based adsorbents for efficient removal of Cr (VI). J Hazard Mater. 2018;352:27-35.

104. Zhanhua H, Bin Z, Guizhen F. Adsorption behavior of $\mathrm{Cr}(\mathrm{VI})$ from aqueous solutions by microwave modified porous larch tannin resin. Bioresources. 2013;8(3):4593-608.

105. Shruti S, Punita U, Khosa MA. Overview of wastewater treatment methods with special focus on biopolymer chitin-chitosan. Int J Biol Macromol. 2019; 121:1086-100

106. Stevens WF, et al. A. Domard: Proc. 2nd Asia Pacific Symp. On 'chitin and chitosan'. Bangkok: Asian institute of Technology; 1996. p. 1-12.

107. Wu FC, Tseng RL, Juang RS. A review and experimental verification of using chitosan and its derivatives as adsorbents for selected heavy metals. $J$ Environ Manag. 2010;91(4):798-806.

108. Baran A, Bıçak E, Baysal ŞH, Önal S. Comparative studies on the adsorption of $\mathrm{Cr}(\mathrm{VI})$ ions on to various sorbents. Bioresour Technol. 2007;98(3):661-5.

109. Roberto SCT Jr, Schons CA, Luiz DG. Adsorption of $\mathrm{Cr}(\mathrm{VI})$ by chitosan with different deacetylation degrees. Desalin Water Treat. 2013;51(40-42):7690-9.

110. Pooja S, Nagendran R. A comparative study of sorption of chromium (III) onto chitin and chitosan. Appl Water Sci. 2016;6(2):199-204.

111. Schmuhl R, Krieg HM, Keizer K. Adsorption of cu (II) and $\mathrm{Cr}(\mathrm{VI})$ ions by chitosan: kinetics and equilibrium studies. Water SA. 2001;27(1):1-7.

112. Ramnani SP, Sabharwal S. Adsorption behavior of $\mathrm{Cr}(\mathrm{VI})$ onto radiation crosslinked chitosan and its possible application for the treatment of wastewater containing Cr (VI). React Funct Polym. 2006:66(9):902-9.

113. Guibal E. Interactions of metal ions with chitosan-based sorbents: a review. Sep Purif Technol. 2004;38(1):43-74.

114. Singh DK, Ray AR. Characterization of grafted chitosan films. Carbohydr Polym. 1998;36:251-5.

115. Yang L, Hsiao WW, Chen P. Chitosan-cellulose composite membrane for affinity purification of biopolymers and immunoadsorption. J Membr Sci. 2002:197:185-97.

116. Rathinam K, Sankaran M. Synthesis, characterization and $\mathrm{Cr}(\mathrm{VI})$ uptake studies of polypyrrole functionalized chitin. Synth Met. 2014;198:181-7.

117. Rathinam K, Sankaran M. Synthesis, characterization and Cr (VI) uptake study of polyaniline coated chitin. Int J Biol Macromol. 2015;72:235-42.

118. Liang $X$, Xiaoyu F, Runmei L. Efficient removal of $\mathrm{Cr}(\mathrm{VI})$ from water by quaternized chitin/branched polyethylenimine biosorbent with hierarchical pore structure. Bioresour Technol. 2018;250:178-84.

119. Sebastian S, Rodrigues Simone CG, Ye X. Phosphonium-enhanced chitosan for Cr (VI) adsorption in wastewater treatment. Carbohydr Polym. 2019;211:249-56.

120. Khalil Tarek E, Elhusseiny Amel F, Ali E-d, et al. Functionalized chitosan nanocomposites for removal of toxic $\mathrm{Cr}(\mathrm{VI})$ from aqueous solution. React Funct Polym. 2020;146. https://doi.org/10.1016/j.reactfunctpolym.2019. 104407.
121. Copello GJ, Varela F, Vivot R. Martinez. Immobilized chitosan as biosorbent for the removal of $\mathrm{cd}(\mathrm{II}), \mathrm{Cr}(\mathrm{III})$ and $\mathrm{Cr}(\mathrm{VI})$ from aqueous solutions. Bioresour Technol. 2008;99(14):6538-44.

122. Wei Z, Shilu Z, Wang J. Hybrid functionalized chitosan-Al2O3@SiO2 composite for enhanced Cr (VI) adsorption. Chemosphere. 2018;203:188-98.

123. Kousalya GN, Gandhi M. Rajiv, Meenakshi S. removal of toxic $\mathrm{Cr}(\mathrm{VI})$ ions from aqueous solution using Nano-hydroxyapatite-based chitin and chitosan hybrid composites. Adsorpt Sci Technol. 2010;28(1):49-64.

124. Witus LS, Francis MB. Using synthetically modified proteins to make new materials. Acc Chem Res. 2011:4:774-83.

125. Deschamps P, Kulkarni PP, Gautam-Basak M, Sarkar B. The saga of copper (II)-L-histidine. Coord Chem Rev. 2005;249:895-909.

126. Shimazaki Y, Takani M, Yamauchi O. Metal complexes of amino acids and amino acid side chain groups. Structures and properties. Dalton Trans. 2009; 38:7854-69. https://doi.org/10.1039/b905871k.

127. Yamauchi O, Odani A, Takani M. Metal-amino acid chemistry. Weak interactions and related functions of side chain groups. J Chem Soc Dalton Trans. 2002;38:3411-21. https://doi.org/10.1039/b202385g.

128. Imaz I, Rubio-Martınez M, An J, Sole-Font I, Rosi NL, Maspoch D. Metalbiomolecule frameworks (MBioFs). Chem Commun. 2011;47:7287-302.

129. Vandenbossche $M$, Jimenez $M$, Casetta M. Remediation of heavy metals by biomolecules: a review. Crit Rev Env Sci Technol. 2015;45(15):1644-704.

130. El-Sherif Iman Y. Tolani Sagar, Ofosu, Kennedy. Polymeric nanofibers for the removal of Cr (III) from tannery waste water. J Environ Manage. 2013;129:410-3.

131. Yang $\mathrm{R}$, Aubrecht Katherine $\mathrm{B}, \mathrm{Ma} \mathrm{H}$. Thiol-modified cellulose nanofibrous composite membranes for chromium (VI) and lead (II) adsorption. Polym. 2014;55(5):1167-76.

132. Yana B, Ankur S, Dinesh M. Lead and chromium adsorption from water using L-cysteine functionalized magnetite (Fe3O4) nanoparticles. Sci Rep. 2017;7. https://doi.org/10.1038/s41598-017-03380-x.

133. Murat U, Esra F, Emir O. New generation ion-imprinted nanocarrier for removal of $\mathrm{Cr}(\mathrm{VI})$ from wastewater. J Nanopart Res. 2013;15(8). https://doi. org/10.1007/s11051-013-1833-9.

134. Augustine A, Kalai SM, Rajeswari A. Preparation and characterization of aspartic acid doped polypyrrole for the efficient removal of $\mathrm{Cr}(\mathrm{VI})$ from aqueous solution. J Water Process Eng. 2016;11:162-73.

135. Yao J, Xu H, Wang J, Jiang M, Ouyang P. Removal of Cr (III), Ni (II) and Cu (II) by poly( $(\gamma$-glutamic acid) from Bacillus subtilis NX-2. J Biomater Sci Polym Ed. 2007;18(2):193-204.

136. Ma B, Qiao X, Hou X, Yang Y. Pure keratin membrane and fbers from chicken feather. Int J Biol Macromol. 2016;89:614-21.

137. Helan Z, Fernando C, Montserrat L-M. Valorization of keratin biofibers for removing heavy metals from aqueous solutions. Text Res J. 2019;89(7):1153-65.

138. Yuan Z, XiaoXiang Z, MeiHua Z. Cr (VI) adsorption on a thermoplastic feather keratin film. Desalin Water Treat. 2014;52(13-15):2786-91.

139. Gao P, Zhenhong L, Wu X. Biosorption of chromium (VI) ions by deposits produced from chicken feathers after soluble keratin extraction. CLEAN-Soil Air Water. 2014;42(11):1558-66.

140. Kumar MN, Sambrita B. Potentiality of waste human hair towards removal of chromium (VI) from solution: kinetic and equilibrium studies. Appl Water Sci. 2019;9(3). https://doi.org/10.1007/s13201-019-0929-5.

141. Jana B, Angela K, Klaudia J. Some Properties of Electron Beam-Irradiated Sheep Wool Linked to Cr (III) Sorption. Molecules. 2019;24(23). https://doi. org/10.3390/molecules24234401.

142. Saucedo-Rivalcoba V, Martinez-Hernandez AL, Martinez-Barrera G. Removal of hexavalent chromium from water by polyurethane-keratin hybrid membranes. Water Air Soil Poll. 2011;218(1-4):557-71.

143. Annalisa A, Cinzia T, Claudia V. Study on the adsorption of chromium (VI) by hydrolyzed keratin/polyamide 6 blend Nanofibres. J Nanosci Nanotechno. 2012;12(9):7250-9.

144. Cobbett CS, Goldsbrough P. Phytochelatins and metallothioneins: roles in heavy metal detoxification and homeostasis. Ann Rev Plant Biol. 2002;53:159-82.

145. Murphy A, Zhou J, Goldsbrough PB, Taiz L. Purification and immunological identification of Metallothioneins 1 and 2 from Arabidopsis thaliana. Plant Physiol. 1997;113:1293-301.

146. Rauser WE. Structure and function of metal chelators produced by plants: the case for organic acids, amino acids, phytin, and metallothioneins. Cell Biochem Biophys. 1999;31:19-48.

147. Achard-Joris M, Moreau JL, Lucas M, Baudrimont M, Mesmer-Dudons N, Gonzalez P, Boudou A, Bourdineaud JP. Role of metallothioneins in 
superoxide radical generation during copper redox cycling: defining the fundamental function of metallothioneins. Biochimie. 2007;89:1474-88.

148. Blindauer CA. Lessons on the critical interplay between zinc binding and protein structure and dynamics. J Inorg Biochem. 2013:121:145-55.

149. Moreau JL, Baudrimont M, Carrier P, Peltier G, Bourdineaud JP. Metal binding and antioxidant properties of chimeric tri- and tetra-domained metallothioneins. Biochimie. 2008;90:705-16.

150. Ruigang Z, Huilan Y. Enhanced Cr6+ biosorption from aqueous solutions using genetically engineered Saccharomyces cerevisiae. Desalin Water Treat. 2017;72:290-9.

\section{Publisher's Note}

Springer Nature remains neutral with regard to jurisdictional claims in published maps and institutional affiliations.

\section{Submit your manuscript to a SpringerOpen ${ }^{\odot}$ journal and benefit from:}

- Convenient online submission

- Rigorous peer review

- Open access: articles freely available online

High visibility within the field

- Retaining the copyright to your article

Submit your next manuscript at $\boldsymbol{\nabla}$ springeropen.com 